AperTO - Archivio Istituzionale Open Access dell'Università di Torino

A Tool for Semi-Automatic Geostructural Survey Based on DTM - a Case Study from NW Italy

This is a pre print version of the following article:

Original Citation:

Availability:

This version is available http://hdl.handle.net/2318/154550

since 2017-05-25T12:24:53Z

Publisher:

A.A. Balkema Publishers, member of Taylor and Francis Group

Terms of use:

Open Access

Anyone can freely access the full text of works made available as "Open Access". Works made available under a Creative Commons license can be used according to the terms and conditions of said license. Use of all other works requires consent of the right holder (author or publisher) if not exempted from copyright protection by the applicable law. 


\title{
A Tool for Semi-Automatic Geostructural Survey Based on DTM - a Case Study from NW Italy
}

\author{
S. Bonetto
}

Department of Earth Sciences, University of Turin, Valperga Caluso 35, 10125 Turin, Italy (sabrina.bonetto@unito.it)

A. Facello

CNR-IRPI, Strada delle Cacce,73 - 10135 Torino, Italy (anna.facello@irpi.cnr.it)

G. Umili

Department of Civil, Environmental and Territory Engineering, University of Parma, Parco Area delle Scienze 181/A, 43124 Parma, Italy (gessica.umili@unipr.it)

ABSTRACT: Lineament analysis constitutes an important part in the hydrogeology/tectonic studies for the delineation of major structural units, analysis of structural deformation patterns and identification of geological boundaries. In the last years, the remote sensing data have been used as a source of information for the detection of tectonic structures. In this paper, the authors present a new approach for semi-automatic extraction and characterization of geological lineaments. The overall positive aspects of this semi-automatic process were found to be the rapidity of preliminary assessment, the possibility to identify the most interesting portions to be investigated and to analyze zones that are not directly accessible. This method has been applied to a geologically well-known area (the Argentera Massif domain) in order to validate the results of the software processing with literature data. Results obtained are discussed and preliminary remarks are put forward.

\section{INTRODUCTION}

The remote sensing data provide fast and relatively cheap information, complementary to classical field geology as source of information for the detection of tectonic structures such as faults, large-scale fractures and fracture zones (Hashim et al, 2012, Wladis, 1999). Lineament analysis constitutes an important part in the domains related to mineral prospecting, hydrogeology studies, tectonic studies for the delineation of major structural units, analysis of structural deformation patterns and identification of geological boundaries.

Lineament maps prepared by conventional field mapping techniques cannot identify all of the lineaments existing in the area, due to the enlarged scale and reduced view/scope of the mapper. In contrast, the remote sensing, with progressive development in the image enhancement techniques, is an opportunity to prepare relatively more reliable and comprehensive lineament maps. The wide ground coverage and relative high resolution, with respect to scale presented by the satellite images, also enables regional and local lineament analysis.

In recent years, space-borne satellite and highaltitude aircraft images and their products, such as Digital Terrain Models (DTM), have been providing observations of these lineaments and their relationships to nearby geomorphic and geologic features that are not easily apparent from the ground through onsite field mapping.
In literature, approaches for the extraction of geological lineaments from images can be grouped into three main categories: (i) manual extraction (Jordan and Schott, 2005), (ii) semi-automatic extraction (Jordan et al., 2005; Lim et al., 2001), and (iii) automatic extraction (Masoud and Koike, 2011; Saadi et al., 2011). Manual and semi-automatic approaches are greatly influenced by the experience of the analyst, while automatic extraction depends on the algorithms efficiency and on the information content in the image (Hashim et al, 2012).

Normally, lineaments can be detected due to their geomorphological features, such as morphotectonic elements, drainage network offsets and stream segment alignments, and/or spectral criterion, such as tonal change, pattern and textures, using (stereo-) aerial photographs and other remotely sensed imagery. Regarding the DTM, this has been used as shaded relief model either alone or in combination with remotely sensed images on a regional scale. Moreover, three-dimensional view with image drape and digital cross sections have been used for morphotectonic investigations (Jordan et al., 2005).

In this paper, authors propose the use of an innovative method for the extraction of geological features using a semi-automatic approach based on DTM. The method will be discussed and presented in the following sections. The overall positive aspects of this semi-automatic process were found to be the rapidity of preliminary assessment, the possibility to identify the most interesting portions 
to be investigated and to analyze zones that are not directly accessible.

\section{METHODOLOGY}

\subsection{Software CurvaTool}

The method presented here is based on the assumption that a geological lineament can be geometrically identified as a convex or concave edge of the surface of a DTM.

The code CurvaTool (Umili et al., 2013) was originally developed to automatically detect edges on DSM (Digital Surface Model) of natural rock mass outcrops, assuming that they represent the discontinuity traces. In this work the code CurvaTool has been applied to DTM of large portion of territory in order to automatically detect edges representing geological lineaments. As natural outcrops, also portions of territory can have an infinite variety of shapes and their dimensions can be very different, but a common characteristic is generally their non-planar surface. In fact, the surface has often edges, that can be both asperities or depressions.

The code quantifies the non-planarity by means of principal curvature values associated to the DSM/DTM points; the user is asked for two thresholds on principal curvature: the first one to detect significant convex edges and the second one to detect significant concave edges. After the identification, edges are segmented in order to obtain the segments that better interpolate the polyline.

Post-processing operations are required in order to filter and to classify segments representing items of interest among all the reconstructed edges: therefore specific algorithms, called Filter in the following, have been created to perform these operations. The user is asked for the minimum edge length and the orientations of the expected clusters of lineaments (expressed by an angle respect to the North and the relative standard deviation). Filter code deletes edges shorter than the fixed length and classifies the remaining attributing each edge to the correspondent input cluster. Non-classified edges are recorded as "others".

DSM/DTM resolution has a direct influence on results accuracy and completeness: in fact the sampling step to collect points on the surveyed object and, consequently, the amplitude of the triangles of the digital model, influence the quality of the approximation of the real surface. In addition, the decrease of the resolution has an effect of "smoothing" and deterioration of the edges of the surface, which reduces the range of principal curvatures, and also depending on the triangulation, disrupts or alters the continuity of the edges. Thus, the decrease of the resolution decreases both the accuracy and completeness of the extracted edges from the real edges.

\section{TEST AREA: BAGNI DI VINADIO AND TERME DI VALDIERI REGIONS}

\subsection{The geological and structural setting of the Argentera Massif}

The Argentera Massif (AM) is located in the southernmost Western European Alps, named Maritime Alps. It is located at the border between Italy and France and it belongs to the External Crystalline Massif of the central-Western Alps (Fig. 1).

It covers an area of about $1000 \mathrm{~km}^{2}$ and has an NW-SE oriented elliptical shape, $25 \mathrm{~km}$ wide and 60 $\mathrm{km}$ long. The main fluvial systems of the Massif are the Gesso and Stura valleys in Italy and the Tinée and Vesubie valleys in France. The maximum elevations exceed $3000 \mathrm{~m}$ a.s.l. and the landscape is the product of glacial, periglacial, hillslope and fluvial processes (Musumeci et al., 2003). The valleys were deeply shaped by Quaternary glaciers that abandoned large frontal and lateral moraines from 700 to $2600 \mathrm{~m}$ a.s.l.(Federici and Pappalardo, 1991). Four main rivers cross the massif: the Gesso and Vesubie River in the South and the Stura di Demonte and Tinée Rivers in the north.

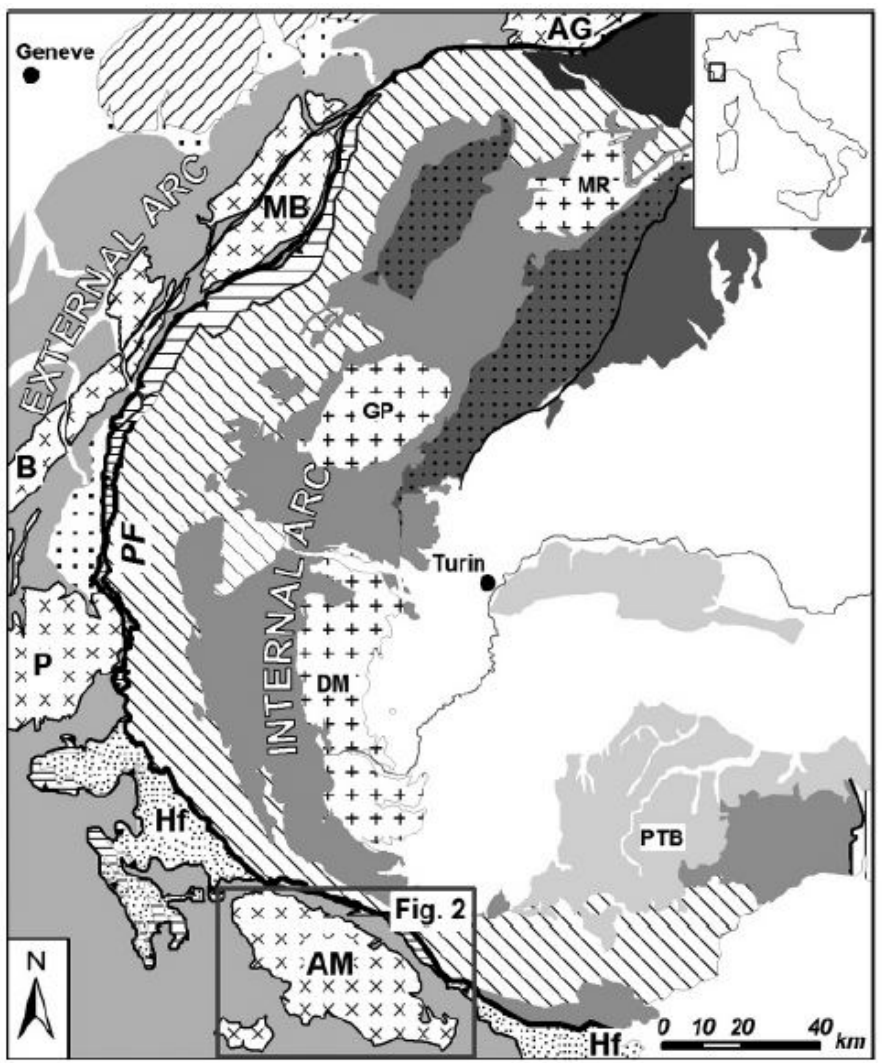

Figure 1. Central-Western Alps and adjacent regions, with location of the study area (in the inset) (Source Baietto et al., 2009) 
The AM has been interpreted as a slice of preTriassic European cristalline basement, cropping out from the sedimentary cover at the footwall of the Penninic Front Thrust. It is mainly composed by high-grade metamorphic rocks (schist, migmatitic paragneiss, amphibolites, diatexite and anatectic granitoid), locally intruded by post metamorphic granitic bodies (Bogdanoff et al., 1991; Fry, 1989).

The crystalline rocks are unconformably overlaid by Triassic to Early Cretaceous carbonates that are partly detached from the basement at the level of the Late Triassic evaporite (Faure-Muret, 1955; Malaroda et al., 1970).

A great structural complexity of the basementcover relationship characterized the AM, particularly in the Gesso and Stura Valley, where erosionexhumed basement slices are tectonically pinched in the cover succession. In particular, in Alpine age the basement was mainly deformed in a brittle way, while the cover succession was deformed more plastically and SW-verging kilometric folds with NW-SE strike axes are associated to the thrusting of the basement. Inside the crystalline basement the strain related to plastic folding in the cover is accommodated by brittle NE-vergent reverse shears related to NNE-SSW compression.

In general, the basement-cover contact strikes mainly NW-SE, but the structural setting is complicated by the presence of high angle strike slip faults mainly represented by two conjugate systems striking NW-SE and NE-SW (locally turning into ENE-WSW), whose the NW-SE one is the most important. These structures result of late-Alpine brittle reactivations of networks of pre-Alpine and early-Alpine ductile shear zones, strike-slip and reverse faults (Bogdanoff et al., 1991; Musumeci et al., 2003; Corsini et al. 2004).

The high angle shear zone are discontinuous faults which sometimes shows en echelon distribution. Three main high angle shear zone cross the AM: the NE-SE Valletta Shear Zone (VSZ), the Bersezio Shear Zone (BSZ) (Faure-Muret, 1955; Bogdanoff, 1986; Vernet, 1965; Horrenberger et al., 1978) and the E-W Fremamorta Shear Zone (FSZ) (Fig. 2).

The seismic and GPS data document that the area is still tectonically active with crustal shortening of 2-4 $\mathrm{mm} / \mathrm{y}$ induced by N-S to NE-SW compression (Madeddu et al., 1996; Ribolini et al., 2008), especially in the axial region of the massif (Perello et al., 2001). The present crustal mobility of Argentera is also indicated by PS data (Morelli at al., 2011).

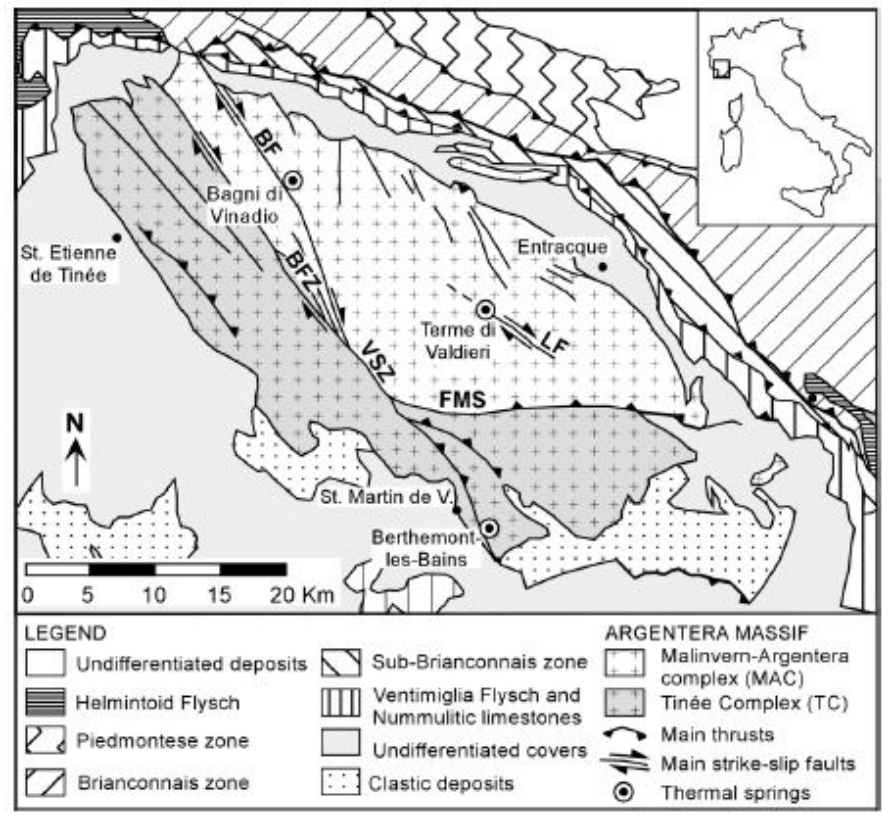

Figure 2. Tectonic sketch map of the Argentera Massif and adjoining regions. BFZ: Bersezio Fault Zone, BF: Bersezio Fault, VSZ: Valletta Shear Zone, FMS: Fremamorta Shear Zone, VMF: LF: Lorusa Fault. Hydrothermal springs discharge at the sites of Bagni di Vinadio (1300 m; I), Terme di Valdieri (1370 m; I) (Source: Baietto et al., 2009).

\section{TEST AREA: BAGNI DI VINADIO AND TERME DI VALDIERI REGIONS}

The AM has been chosen as alpine test area for the Curvatool software validation, due to the several literature data and the demonstrated correspondence between morphological elements and structural lineaments in this sector. Geological field surveys in the area have shown that aligned valleys, scarps, saddles and crests correspond to faulted zones and fractured rocks. In particular, in reason of the regional scale of the work, the surface edges detected by the software mainly correspond to crests and valleys.

In order to facilitate the data processing and obtain accurate results, the AM has been split into two sectors: the Bagni di Vinadio area (NW) and the Terme di Valdieri area (SE).

The Curvatool processing of the Bagni di Vinadio area shown a preferred orientation of the lineaments, primarily, in the NW-SE direction, secondly in the NE-SW. In particular, a non homogeneous distribution of the lineaments in the area has been observed and three different domains should be recognized: a SW sector (as regards the Tinée-Stura watershed) with a small number of iso-oriented lineaments mainly NE-trending, a central sector with the highest frequency of lineaments principally NWSE striking and a NE sector (as regards the Stura River) characterized by an equivalent distribution of NW-SE and NE-SW (Fig. 3) 


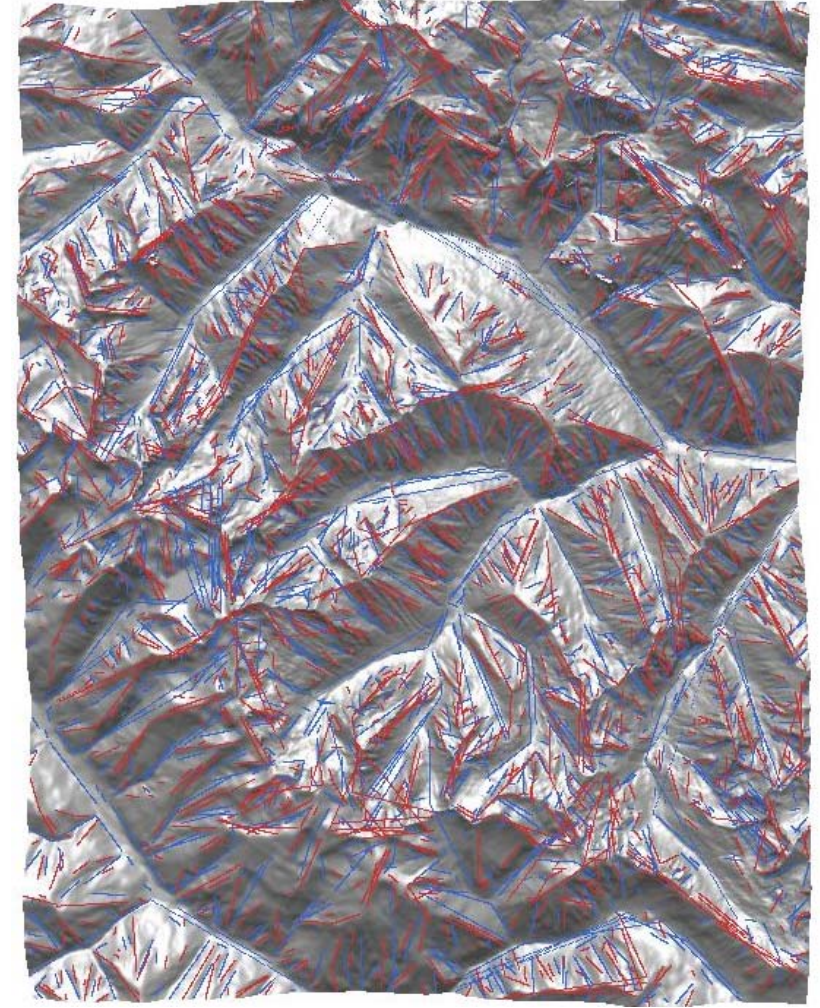

Figure 3. Image of Bagni di Vinadio DTM with all lineaments extracted by CurvaTool

In the Terme di Valdieri area NW-SE, NE-SW and E-W lineaments have been pointed out. The NW-SE and NE-SW trending lineaments are predominant and show an homogeneous distribution in the whole area, whereas the E-W ones are mainly located in the southern and southeastern sector. A fourth lineament system N-S oriented has been detected by the software (Fig. 4).

The data automatically derived by the software were successively compared with literature data, in order to validate the method. Some Filters were applied (Table 1, Table 2), coherently with geomorphological and structural literature data.

Table 1. Clusters orientation input in Filter to classify lineaments extracted with CurvaTool by Bagni di Vinadio DTM

\begin{tabular}{|l|l|l|}
\hline set & $\begin{array}{l}\text { Orientation } \\
\text { (respect to North) } \\
{\left[{ }^{\circ}\right]}\end{array}$ & $\begin{array}{l}\text { Variability range } \\
\text { assigned to orientation } \\
{\left[{ }^{\circ}\right]}\end{array}$ \\
\hline 1 & 140 & \pm 10 \\
\hline 2 & 55 & \pm 5 \\
\hline
\end{tabular}

Table 2. Clusters orientation input in Filter to classify lineaments extracted with CurvaTool by Terme di Valdieri DTM

\begin{tabular}{|l|l|l|}
\hline set & $\begin{array}{l}\text { Orientation } \\
(\text { respect to North) } \\
{\left[{ }^{\circ}\right]}\end{array}$ & $\begin{array}{l}\text { Variability range } \\
\text { assigned to orientation } \\
{\left[{ }^{\circ}\right]}\end{array}$ \\
\hline 1 & 125 & \pm 15 \\
\hline 2 & 50 & \pm 10 \\
\hline 3 & 0 & \pm 20 \\
\hline 4 & 90 & \pm 19.99 \\
\hline
\end{tabular}

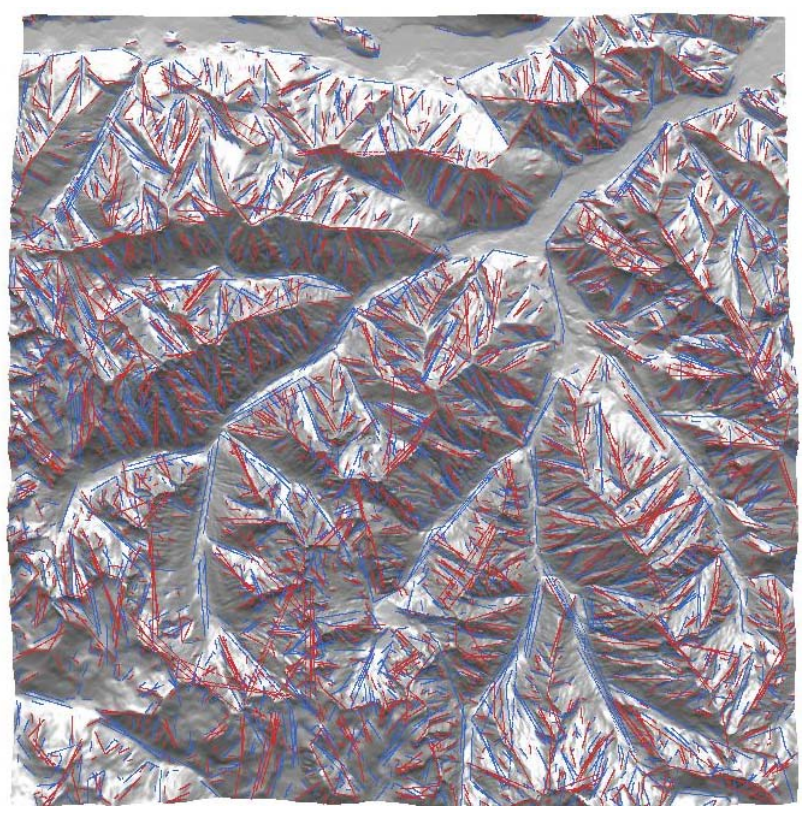

Figure 4. Image of Terme di Valdieri DTM with all lineaments extracted by CurvaTool.

The images obtained by Filters application clarify a substantial and significant consistency between the CurvaTool lineaments and the expected structural features coming from manual extraction and field surveys (Figs. 5, 6).

\section{FINAL REMARKS}

The Curvatool NW-SE trending lineaments turned out as the main system in either studied areas, coherently with both regional and meso-scale structural data. The NW-SE lineaments strike is coherent with the direction of the main alpine structures. As mentioned in the previous paragraph, two of the main high angle shear zones crossing the AM (Valletta and Bersezio Shear Zone) are NW-SE oriented, as well as a NW-SE striking schistosity and cleavage (S1 and S2) are observed directly in the field in the Mesozoic meta-sedimentary covers of the AM (Perello at al., 2001; Baietto et al., 2009). It corresponds to an axial plane schistosity related to the SW-verging folds and to SW-directed brittle thrusting of the basement above the cover (Perello et al., 2001). In particular in the Bagni di Vinadio area, the alignment of long single segments detected by Curvatool and their high density in correspondence of NW-SE elongated strips seem to have a strong correspondence with the location of the Bersezio and the Valletta Faults and with their deformation zones.

As regards to the NE-SW striking Curvatool lineaments pointed out in both Valdieri and Vinadio area, they could be associated to the NE-SW conjugate system that, together with the NW-SE system, get rise to the high angle strike-slip faults (Perello et al., 2001). 

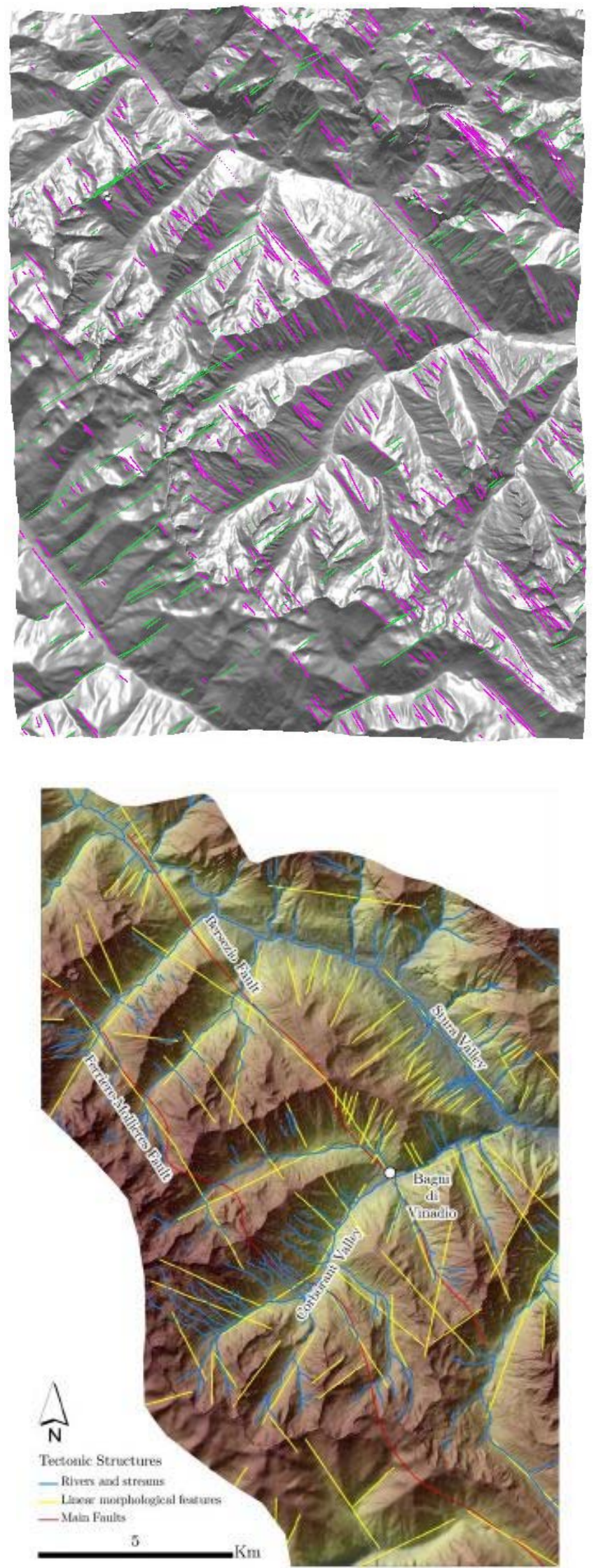

Figure 5: a). Image of lineaments extracted by CurvaTool from Bagni di Vinadio DTM, classified by Filter according to set in Table 1: set 1(fucsia), set 2 (green); b) synthesis of Bagni di Vinadio Literature data: relation between linear morphological features (yellow), major faults (red) and drainage network (blue) (Guglielmetti et al., 2012 ).
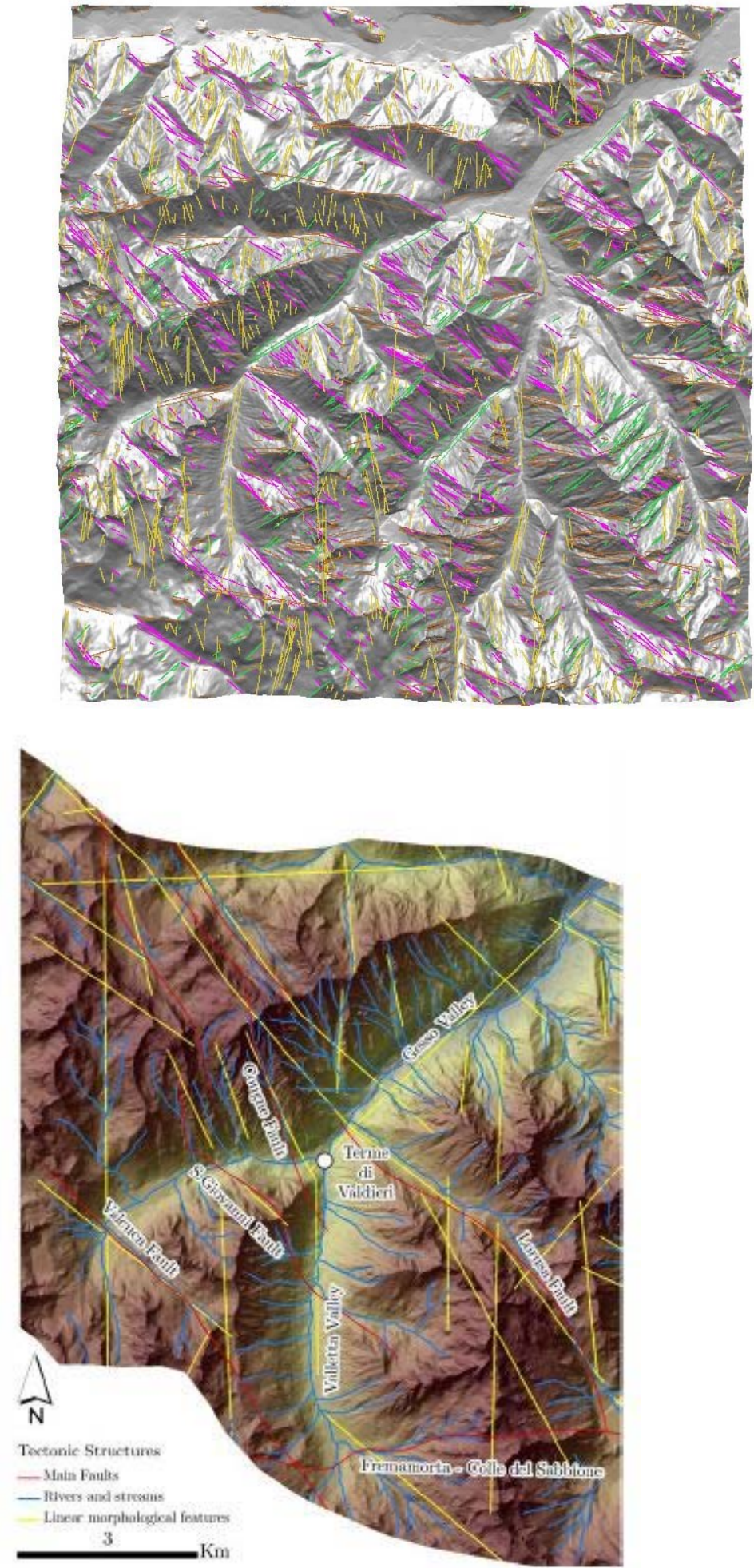

Figure 6: a) Image of lineaments extracted by CurvaTool from Terme di Valdieri DTM, classified by Filter according to set in Table 2: set 1(fucsia), set 2 (green), set 3 (yellow), set 4 (brown); b) synthesis of Terme di Valdieri Literature data: relation between linear morphological features (yellow), major faults (red) and drainage network (blue) (Guglielmetti et al., 2012 ).

The E-W striking lineaments, detected by Curvatool in particular in the Terme di Valdieri area, could be coherently associated to the Fremamorta Shear Zone which is located to the south of the studied area. 
In fact the E-W Curvatool lineaments are mainly pointed out in the southern sector of the Terme di Valdieri area.

Moreover, as regard to the morphological literature data, the trends of Curvatool lineaments are coherent with the preferred orientation of the draindage network as observed by Musumeci et al. (2003) and Ribolini et al. (2008).

Furthermore, it has been noticed that, in comparison with the Bagni di Vinadio, the Terme di Valdieri area shows a higher dispersion in the directions of the Curvatool lineaments (at least four lineaments systems were recognized). Also this feature is validated by literature. Some authors (Ribolini et al., 2008, Musumeci et al., 2003, Morelli et al., 2011) report that the SE portion of the Massif is the area whit the highest and recent tectonic uplift, in consequence it is characterized by the highest elevations and dendritic drainage network, the last one causing a lack of preferred orientation of the drainage (crests and valleys).

On the contrary, the lower relief of the NW sector of the AM (where Bagni di Vinadio is located) results in a generally higher sensitivity of the drainage network to faults and fracture systems which determine preferential orientation of the lineaments as detected by Curvatool.

In general, moving toward SE along the NW-SE direction, it has been observed an increasing in the presence of NE-SW and N-S lineaments, according to literature (Ribolini et al., 2008).

In conclusion, preliminary results of software application are satisfactory in reason of their good correspondence with structural and morphological literature data, particularly as regard to strike and distribution of the main lineaments systems. Subsequent investigations and statistical processing of the data have to be accomplished to validate and improve the software.

\section{REFERENCES}

BAIETTO, A, PERELLO, P., CADOPPI, P., MARTINOTTI G., 2009. Alpine tectonic evolution and thermal water circulations of the Argentera Massif (South-Western Alps). Swiss J. Geosci., 102, 223-245.

BOGDANOFF, S. 1986. Evolution de la partie occidentale du Massif cristallin externe de 1'Argentera. Place dans 1'arc Alpin. Géologie de France, 4, 433-453.

BOGDANOFF, S., MENOT, R.P., VIVIER, G., 1991. Les Massifs Cristallins Externes des Alpes Occidentales francaises, un fragment de la zone interne varisque. Science Geologique Bullettin 44 (3-4), 237-285

CORSINI, M., RUFFET, G. \& CABY, R. 2004: Alpine and late-hercynian geochronological constraints in the Argentera Massif (Western Alps). Eclogae Geologicae Helvetiae 97, 3-15.

FAURE-MURET, A. 1955. Etudes géologiques sur le massif de 1'Argentera. BOILlOT, G. (eds.) Les Marges continentales actuelles et fossiles autour de la Mercantour et ses enveloppes sédimentaires. Mémoires pour servir à l'explication de la carte géologique détaillé de la France. Paris: Imprimerie Nationale, 336 pp.

FEDERICI P.R and PAPPALARDO M., 1991. Nota introduttiva alla morfologia glaciale della Valle del Gesso di Entraque (Gruppo dell'Argentera, Alpi Marittime) Gruppo Nazionale di Geografia Fisica e Geomorfologia, guida all'escursione primaverile, Cuneo 28-31 maggio,pp13-16.

FRY, N. 1989. Southwestward thrusting and tectonics of the western Alps. In: COWARD, M., DIETRICH, D., PARK, $R$. G. (eds.) Alpine Tectonics. Geological Society, London, Special Publications, 45, 83-111.

GUGLIELMETTI, L., 2012. Multidisciplinary approach of geothermal exploration in the Argentera Massif (Southwestern Alp). Phd Thesis. Department of Earth Science, Torino University, 193pp.

HASHIM M, AHMAD S, JOHARI MD, BEIRANVAND POUR, 2013, Automatic linea-ment extraction in a heavily vegetated region using Landsat Enhanced Thematic Mapper (ETM+) imagery Advances in Space Research Vol 51, Issue 5, pp 874-890.

HORRENBERGER, J. C., MICHARD, A. \& WERNER, P. 1978: Le couloir de décrochement de Bersezio en HauteStura, Alpes externes, (Italie), structure de compression sub-méridienne. Sciences Géologiques Bulletin 31, 15-20

JORDAN, G., SCHOTT, B., 2005. Application of wavelet analysis to the study of spatial pattern of morphotectonic lineaments in digital terrain models. A case study. Remote Sens-ing of Environment Vol 94, Issue 1, pp 31-38.

LIM, C.S., IBRAHIM, K., TJIA, H.D., 2001, Radiometric and Geometric information con-tent of TiungSat-1 MSEIS data, in: TiungSAT-1: From Inception to Inauguration, pp. 169184.

MADEDDU, B., BÉRTOUX, N., STÉPHAN, J.F., 1996. Champ de contrainte post-pliocene et déformation récentes dans les Alpes sudoccidentales. Bullettin Societé Géoloqique France 167 (6), 797-810.

MALARODA, R., CARRARO, F., DAL PIAZ, G.V., FRANCESCHETTI, B., STURANI, C. \& ZANELLA, E. 1970. Carta geologica del Massiccio dell'Argentera alla scala 1:50.000 e note illustrative. Memorie della Società Geologica Italiana, 9, 557-663.

MASOUD, A., KOIKE, K.,2011, Auto-detection and integration of tectonically significant lineaments from SRTM DEM and remotely-sensed geophysical data. ISPRS J. Photogr. Remote Sens. 66, pp 818-832.

MORELLI M., PIANA F., MALLEN L., NICOLO' G., FIORASO G., 2011: Iso-Kinematic Maps from statistical analysis of PS-InSAR data of Piemonte, NW Italy: Comparison with geological kinematic trends Remote Sensing of Environment V 115, Issue 5, Pages 1188-1201

MUSUMECI G., COLOMBO F., 2002: Late Visean mylonitic granitoids in the Argentera Massif (Western Alps): age and kinematic constraints on the Ferrière-Mollières shear zone. Comptes Rendus de l'Académie des Sciences Serie II 334, 213-220.

MUSUMECI, G., RIBOLINI, A., SPAGNOLO, M., 2003. The effect of late Alpine tectonics in the morphology of the Argentera Massif (Western Alps, Italy-France). Quaternary International 101-102, 191-201.

PERELLO, P., MARINI, L., MARTINOTTI, G. \& HUNZIKER, J.C. 2001. The thermal circuits of the Argentera Massif (western Alps, Italy): An example of low-enthalpy geothermal resources controlled by Neogene alpine tectonics. Eclogae Geologicae Helvetiae, 94, 75-94.

RIBOLINI A., SPAGNOLO M 2008. Drainage network geometry versus tectonics in the Argentera Massif (FrenchItalian Alps). In Geomorphology 93 pp 253-266.

SAADI, N.M., ABDEL ZAHER, M., EL-BAZ, F., WATANABE, K., 2011, Integrated re-mote sensing data utization for investigating structural and tectonic history of 
the Ghadames Basin, Libya. Inter. J. Appl. Earth Obser. Geoinfor. 13,pp 778-791.

UMILI G., FERRERO A.M., EINSTEIN H.H., 2013. A new method for automatic discon-tinuity traces sampling on rock mass 3D model. Computers \& Geosciences $51 \mathrm{pp}$. 182-192.

VERNET, J. 1965: Sur un décrochement horizontal tardif du socle dans la region méridionale de la zone des massifs cristallins externes (massif de l'Argentera, AlpesMaritimes). Comptes Rendus de l'Académie des Sciences de Paris 258, 1358-1360.

WLADIS D, 1999, Automatic Lineament Detection Using Digital Elevation Models with Second Derivative Filters. In Photogrammetric Engineering \& Remote Sensing, Vol. 65, No. 4, pp. 453-458. 